\title{
Media Promosi dan Penjualan Ikan Tuna Loin Pada PT. UD RAUL Berbasis web
}

\author{
Rusman Djafar ${ }^{1}$, Junaidi Noh' ${ }^{2}$, Adelina Ibrahim ${ }^{3}$ \\ Fakultas Teknik, Program Studi Informatika \\ Universitas Muhammadiyah Maluku Utara, Ternate, Indonesia \\ Email: rusmandjafar@gmail.com
}

\begin{abstract}
Abstrak
PT. UD RAUL merupakan perusahaan yang bergerak dalam penjualan ikan tuna loin, Namun dalam pelayanan penjualan PT. UD RAUL seperti pemesanan ikan dan transaksi pembayarann masih bersifat manual dimana pembelian melakukan transaksi pembelian ikan secara langsung PT. UD RAUL yang menjadi salah satu permasalahannya. Dalam hal ini guna mempermudah pelanggan untuk mendapatkan pelayanan tersebut, berdasarkan masalah diatas maka perlu adanya suatu aplikasi Media Promosi Dan Penjualan Ikan Tuna Loin Pada PT. UD RAUL Berbasis Web. Penelitian ini menggunakan Metode Prototype sebagai Metode Pengembangan dan pemodelan Aplikasi menggunakan bahasa pemrograman Java pada bagian web dan bahasa pemrograman PHP Pada bagian Administrator dengan MySQL untuk pengolahan databasenya. Sistem Informasi Penjualan Ikan Tuna Loin Pada PT. UD RAUL Berbasis Web Dapat mengumpulkan, mengidentifikasi, menyimpan, mengolah dan memberikan informasi Penjualan Pada PT. UD RAUL yang menjadi target dalam penelitian ini.
\end{abstract}

Kata Kunci: Website, Promosi, Penjualan, Tuna Loin.

\section{Abstract}

PT. UD RAUL is a company engaged in the sale of tuna loin, however in sales services PT. UD RAUL, such as fish orders and payment transactions, is still manual, where purchases make fish purchases directly. PT. UD RAUL, which is one of the problems. In this case, to make it easier for customers to get these services, based on the above issues, it is necessary to apply for Media Promotion and Sales of Tuna Loin at PT. Web-based bolted application supported Web application for database manager by admin. This research uses the Prototype Method as a method of application development and modeling using the Java programming language on the web and the PHP programming language on the Administrator section with MySQL for database processing. Information System for Tuna Loin Sales at PT. Web-Based UD RAUL Can collect, identify, store, process and provide sales information at PT. UD RAUL, which was the target of this research

Keywords: Website, Promotion, Tuna, Sales.

\section{PENDAHULUAN}

Kemajuan teknologi informasi, mendorong banyak manusia menciptakan inovasi-inovasi baru untuk membantu manusia dalam mendapatkan informasi dengan cepat dan mudah, salah satunya yaitu internet. Seiring dengan kebutuhan manusia yang juga terus bertambah, teknologi memegang peranan yang penting bagi kehidupan manusia. saat ini, siapa yang tidak bisa mengikuti perkembangan teknologi, maka dia pasti menjadi orang yang terbelakang. Media yang paling banyak dignakan memenuhi kebutuhan informasi dan komunikasi adalah komputer dan hendepone yang di jembatan 
oleh internet sehingga perpindahan informasi tidak terbatasi oleh ruang dan waktu.

Dalam dunia bisnis dampak positif teknologi informasi kini tidak hanya bisa dirasakan oleh bisnis dengan skala besar. Usaha kecil menegah yang melibatkan teknologi informasi dan komonikasi

untuk menjalankan usahanya akan dapat mempermudah para usaha untuk menujang aktifitas bisnis. Keterlibatan teknologi informasi dan komunikasi dalam hal ini membuat usaha akan lebih mudah, lebih cepat dan dapat diandalkan untuk menimalkan kesalahan manusia.

PT. UD Raul merupakan salah satu bidang usaha perdagangan enceran hasil perikanan di desa waringi kecamatan obi utara yang menjual ikan tuna loin. namun dengan sistem penjualan yang berjalan sekarang hanya menggunakan ponsel (hp), sehinga penjualan ikan tuna loin di PT. UD Raul masih minim, masalah yang tenjadi pada pihak PT. UD Raul adalah PT. UD Raul itu sendiri belum ada media khusus untuk mempromosikan sekaligus menjual ikan tuna loin dan masalah yang terjadi pada pihak konsumen yaitu konsumen harus datang langsung ke PT. UD Raul apabila ingin mendapatkan informasi jenis dan harga ikan yang di jual, hanya konsumen yang memiliki nomor handphone PT. UD Raul yang bisa memesan ikan tuna loin.

Solusi yang diajukan untuk mengatasi masalah di PT. UD Raul untuk mengembangkan bisnis penjualanya yaitu dengan aplikasi penjualan ikan tuna loin pada PT. UD Raul berbasis web. Fungsi utama aplikasi ini adalah untuk memperluas dan meningkatkan pemasran penjualan ikan tuna loin. konsumen dapat memperoleh informasi mengenai jenis dan harga ikan serta dapat memesan ikan tuna loin di desa waringi hanya dengan menggunakan apliksi tampa harus datang langsung ke PT. UD Raul. Aplikasi ini menyediakan fasilitas-fasilitas seperti jenis dan harga ikan loin beserta gambarnya, sehingga konsumen dapat mengetahui informasi mengenai jenis dan harga ikan loin, serta pelanggan yang dapat membeli ikan tuna loin tidak perlu berlama-lama mengantri saat ingin membeli ikan loin. aplikasi ini bertujuan menyediakan fasilitas pesan antar sehingga pelanggan bisa menghemat waktu dan biaya.

\section{Rumusan Masalah}

Dari latar belakang di atas, obyek yang menjadi permasalahan yaitu :

1. Bagaimana merancang aplikasi penjualan ikan tuna loin berbasis Web sehingga pemasaran dan penjualan menjadi meningkat?

2. Bagaimana mempublikasikan informa si produk-produk ikan tuna loin yang akan dijual pada aplikasi ikan tuna loin berbasis web?

\section{Tujuan Penelitian}

Berdasarkan latar belakang di atas, penulis merumuskan masalah yaitu :

1. Aplikasi ini di terapkan untuk membantu sistem pemasaran dan penjualan ikan tuna loin di PT. UD Raul.

2. Aplikasi ini dapat menampilkan jenis produk ikan tuna loin di PT. UD Raul.

3. Aplikasi ini dapat melayani pemesanan produk ikan tuna loin di PT. UD Raul.

4. Pelanggan yang terdaftar sebagai member dapat membeli ikan tuna loin dan menilai produk dari PT. UD Raul.

\section{Manfaat Penelitian}

Manfaat yang diperoleh dalam pembuatan aplikasi media promosi dan 
penjualan ikan tuna loin pada PT. UD Raul berbasis web, yaitu :

1. Instansi dapat mempublikasikan informasi berhubungan dengan instansinya tersebut melalui internet.

2. Masyarakat Desa Waringi Kecamatan Obi Utara bisa mendapat informasi dengan cepat dan efisien melalui aplikasi penjualan berbasis web tersebut.

\section{Tinjauan Pustaka}

Penilitian ini bembahas tentang " Perancangan Website Sebagai Media Promosi Dan Penjualan Pada Home Industri Abon". Jurnal Teknik Industri, Vol. 15, No. 2, Agustus 2014: 170-181. tujuan dari penelitian ini adalah merancang website sebagai media promosi dan penjualan. Penilitian ini menggunakan Metode pengumpulan data yang dilakukan dengan beberapa tahapan antara lain dengan observasi, interview, dan brainstorming. Data yang dibutuhkan meliputi data umum home industry, data pendukung perancangan program serta user requirement yang berisi keinginan serta atribut yang diperlukan pada saat menggunakan software, dan fungsi-fungsi lain yang diperlukan oleh pengguna. Hasil dari penilitian ini adalah Perancangan website menggunakan sistem penjualan online dengan tool Content Management System (CMS) Opencart. Dengan adanya website ini, kegiatan pemasaran akan lebih efektif dan bisa menaikkan omset penjualan. Shanty Kusuma Dewi Dan Annisa Kesy Garside (2014)

Penilitian ini membahas tentang "Penerapan Business To Customer (B2c) Pada Sistem Penjualan Ikan Bakar Di L2b Berbasis Android". Jurnal Teknologi Terpadu Vol. 3, No. 2, Desember 2011. eISSN 2460-7908. Tujuan dari penelitian ini adalah untuk membuat aplikasi penjualan ikan bakar berbasis Android untuk Ikan Bakar L2B dengan menerapkan konsep Business To Customer (B2C) sehingga dapat memudahkan konsumen dalam memesan dan mengetahui informasi tentang harga jual ikan lewat aplikasi Android. Metode pengembangan perangkat lunak yang digunakan adalah metode Waterfall. Hasil penelitian ini adalah aplikasi ini dapat membantu Ikan Bakar L2B untuk memperluas pemasaran dan meningkatkan penjualan ikan bakar, dan membantu pelanggan yang ingin mendapatkan informasi harganya, dan memesan ikan bakar tanpa perlu datang langsung ke Ikan Bakar L2B. Bella Vannia Daris dan Semlinda (2011)

Penilitian ini membahas tentang "Sistem Penjualan Instan Dengan Etalase Dinding Berbasis Lokasi Menggunakan Android". Jurnal No.14, 0711-376400. Tujuan dari penelitian ini adalah untuk merancang dan mengembangkan sistem penjualan instan dengan etalase dinding berbasis lokasi menggunakan Android. Aplikasi ini dibuat untuk memudahkan masyarakat dalam aktivitas pembelian produk. Dalam pembuatan sistem ini bahasa pemrograman yang digunakan adalah Java, untuk membangun aplikasi Android, sedangkan basis data menggunakan MySQL. Web sederhana juga digunakan admin untuk mengelola produk yang dijual dan pesanan pelanggan.

Pada sistem ini terdapat fitur GPS (Global Positioning System) yang digunakan untuk mengetahui lokasi geografis pelanggan. Metodologi pengembangan sistem yang digunakan adalah metodologi Iterasi. Keluaran yang dihasilkan dari pengembangan sistem ini 
adalah aplikasi penjualan dan aplikasi kurir berbasis Android. Dengan aplikasi kurir, pesanan dapat diantarkan kepada pelanggan dengan lebih mudah ke alamatnya.

Perbedaan dalam penelitian tugas akhir ini dengan penelitian sebelumnya adalah aplikasi penjualan ini selain dapat memberikan laporan penjualan, juga dapat memberikan laporan jumlah Produk Tuna loin yang tersedia di gudang, serta laporan Ikan yang diminati pelanggan setiap bulannya untuk digunakan manajer gudang dalam menentukan prioritas ikan yang dibeli di periode selanjutnya. Rizky Emilia Dan Muhammad Rachmadi (2015).

\section{LANDASAN TEORI}

\section{HTML (Hypertext Markup Laguage)}

HTML Kependekatan dari Hyper Text Markup Language. Dokumen HTML adalah file text murni yang dapat di buat dengan editor text sembarang. Dokumen ini dikenal sebagai web page. File-file HTML ini berisi intruksi-intruksi yang kemudian diterjemahkan browser yang di komputer client sehingga isi informasinya dapat ditampilkan secara visual di komputer pengguna.

HTML dikenal sebagai standar bahasa yang digunakan untuk menampilkan dokumen web. Yang bisa dilakukan dengan HTML yaitu:

1. Mengontrol tampilan dari web page dan contohnya.

2. Mempublikasikan dokumen secara online sehingga bisa di akses dari seluruh dunia.

3. Membuat 0nline from yang bisa di gunakan untuk menangani pendaftaran , transaksi secara online.

Menambahkan objek-objek seperti image, audio, vidio dan juga java applet dalam cokumen HTML. (Kustyahningsih, 2011).

\section{PHP (Perl Hypertext Preprocessor)}

PHP (atau resmanya PHP: Hypertext

Preprosessor) adalah skrip bersifat serverside yang ditambahkan ke dalam HTML. PHP sendiri merupakan singkatan dari personal home Rools. Skrip ini akan membuta suatu aplikasi dapat di itekrasikan kedalam HTML sehingga suatu halaman web tidak lagi bersifat statis, namun menjadi bersifat dinamis. Sifat server side berarti pengerjaan skrip dilakukan di server, baru kemudian hasilnya di kirimkan ke browser. (Kustyahningsih 2011).

\section{Java Script Object Notation (JSON)}

JSON (JavaScript Object Notation) adalah format pertukaran data yang ringan, mudah dibaca dan ditulis oleh manusia, serta mudah diterjemahkan dan dibuat (generate) oleh komputer. Format ini dibuat berdasarkan bagian dari Bahasa Pemprograman JavaScript, Standar ECMA-262 Edisi ke-3 - Desember 1999. JSON merupakan format teks yang tidak bergantung pada bahasa pemprograman apapun karena menggunakan gaya bahasa yang umum digunakan oleh programmer keluarga $\mathrm{C}$ termasuk $\mathrm{C}, \mathrm{C}++, \mathrm{C}$, Java, JavaScript, Perl, Python dll. Oleh karena sifat-sifat tersebut, menjadikan JSON ideal sebagai bahasa pertukaran data [JSON] (Andi juansah 2015).

\section{Flowchart}

Algoritma merupakan suatua alur pemikiran seseorang yang harus dapat dituangkan secara tertulis. Salah satu caranya adalah dengan menggunakan simbol-Simbol / gambar-gambar yang memang sudah standar pada dunia 
komputer. Gambara dan simbol itu disebut dengan Flowchar. Rachamat C. (2010:15).

\section{METODE PENELITIAN}

Metode yang digunakan dalam penelitian ini adalah : Data Primer, data yang diperoleh secara lansung dari pemilik usaha ikan loin di PT.UD Raul Desa Waringi.Data Sekunder, Data yang diperoleh dari referensi yang ada kaitanya dengan media promosi. Untuk pengumpulan data dilakukan

Studi Pustaka

Metode ini digunakan untuk mempelajari berbagai buku literatur yang berhubungan dengan penelitian, internet, buku-buku yang ada kaitanya dengan media promosi ikan tuna loin berbasis web.

Wawancara Metode ini merupakan metode analisis kebutuhan yang dilakukan untuk mencari sesuatu informasi mengenai suatu hal yang berkaitan dengan objek penelitian. Metode ini dilakukan dengan cara mengadakan Wawancara langsung dengan petugas lapangan atau pemilik usaha ikan tuna loin.

\section{Kerangka Berpikir Penilitian}

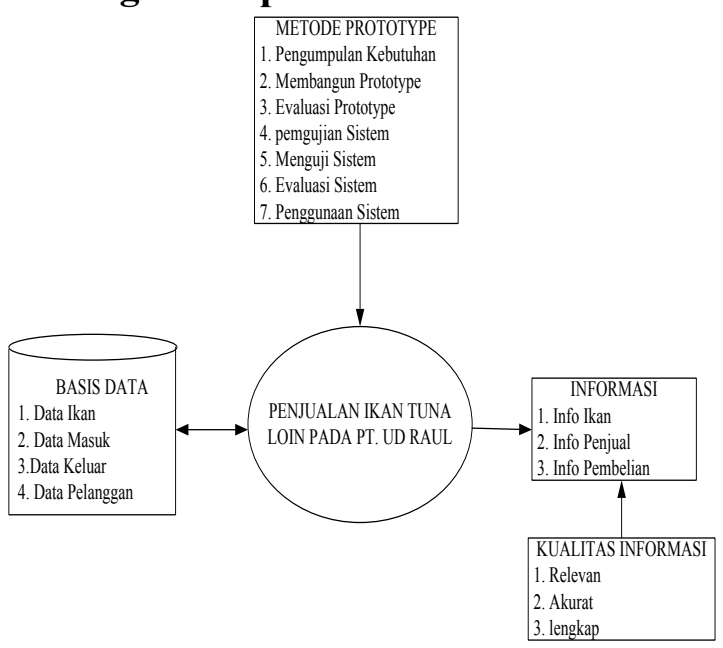

Gambar 1. Kerangka Berfikir Penelitian
PT. UD Raul merupakan perusahaan pemasaran ikan yang berada di kecamatan obi utara kabupaten Halmahera selatan. Sistem pemasaran ikan yang di gunakan pada PT. UD Raul masih konvensional (manual), dalam hal ini pelanggan yang ingin membeli ikan harus datang langsung ke lokasi perusahaan untuk melakukan transaksi pembelian dan juga kurangnya informasi mengenai jenis dan harga ikan kepada pihak pelanggan yang menyebabkan minimnya pelanggan untuk membeli ikan di perusahaan.

Dengan adanya suastu sistem yang sistematis maka dapat mempermudah dalam hal pengelolaan data penjualan maupun promosi ikan pada perusahaan dan juga dapat mempermudah pihak pelanggan untuk mendapatkan informasi mengenai jenis dan harga ikan yang tersedia. Pada penelitian ini peneliti menggunakan metode Prototype sebagai metode pengembangan sistem dan permodelan menggunakan UML (Unified Model Language) sedangkan pembuatan sistem sendiri menggunakan bahasa pemrograman PHP dengan MySQL untuk pengolahan databasenya. Media Promosi dan Penjualan Ikan Tuna Loin Pada PT. UD Raul berbasis web dapat mengumpulkan data, menyimpan, mengelola dan memberikan informasi mengenai jenis dan harga ikan pada perusahanaan yang menjadi target dalam penelitian ini.

1. Dukungan interface yang dapat memberikan kemudahan bagi pengguna aplikasi dalam memberikan informasi Penjualan Ikan Tuna Loin kepada pengguna aplikasi

2. Model pengembangan program yang memungkinkan pengguna untuk melakukan pemesanan pemesan ikan lebih cepat. 
3. Aplikasi Media Promosi Dan Pemjualan Ikan Tuna Loin Pada PT. UD RAUL Berbasis Web dapat membantu pengguna atau masyarakat mendapatkan informasi Pemjualan Ikan Tuna Loin secara cepat dan tepat.

\section{Analisis Sistem Yang Berjalan}

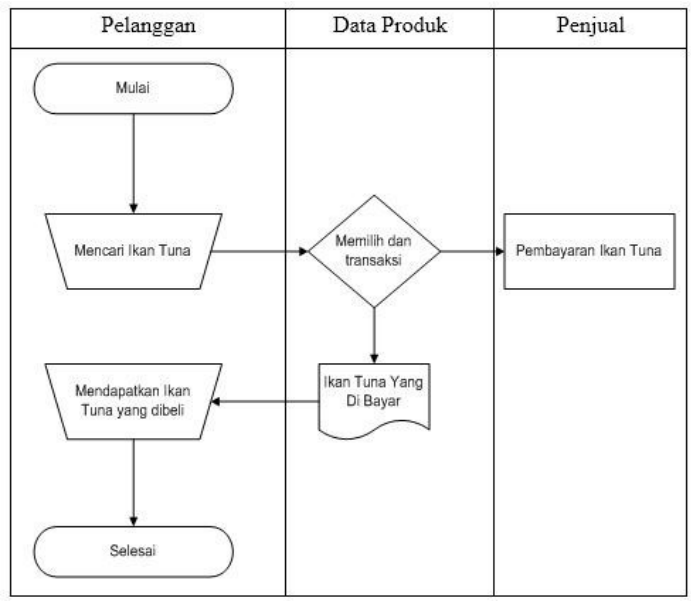

Gambar 2. Sistem yang berjalan.

\section{Analisi Sistem Yang Diusulkan}

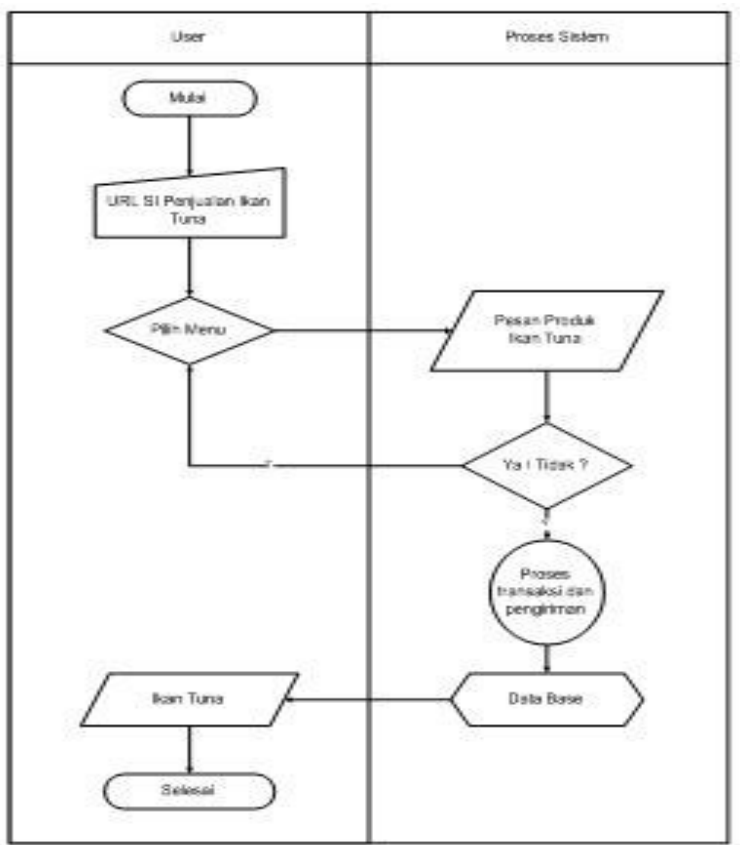

Gambar 3. Sistem yang diusulkan

\section{Analisis Kebutuhan Sistem Perangkat keras (Hardware)}

Perangkat keras yang digunakan adalah sebagai berikut :
1. Processor intel core 2 duo @ $2.00 \mathrm{GHz}$

2. RAM (Random Access Memory) 2 GB

3. Harddisk $500 \mathrm{~GB}$

4. Monitor dengan resolusi $1024 \times 768$

5. Mouse

6. Keyboard

\section{Perangkat lunak (software)}

Perangkat lunak yang di gunakan yaitu :

1. Microsoft Windows 7 sebagai sistem operasi

2. Bahasa pemrograman PHP 5..2.5 dan aplikasi Dreamweaver CS3

3. Aplikasi XAMPP 1.6.6a dan database MySQL.

\section{ERD (Entity Relation Diagram)}

ERD adalah notasi yang digunakan untuk melakukan aktivitas pemodelan data. Atribut dari masing-masing objek data ditulis pada ERD dapat digambarkan dengan menggunakan deskripsi objek data. Adapun ERD yang digunakan pada pengolahan data adalah sebagai berikut :

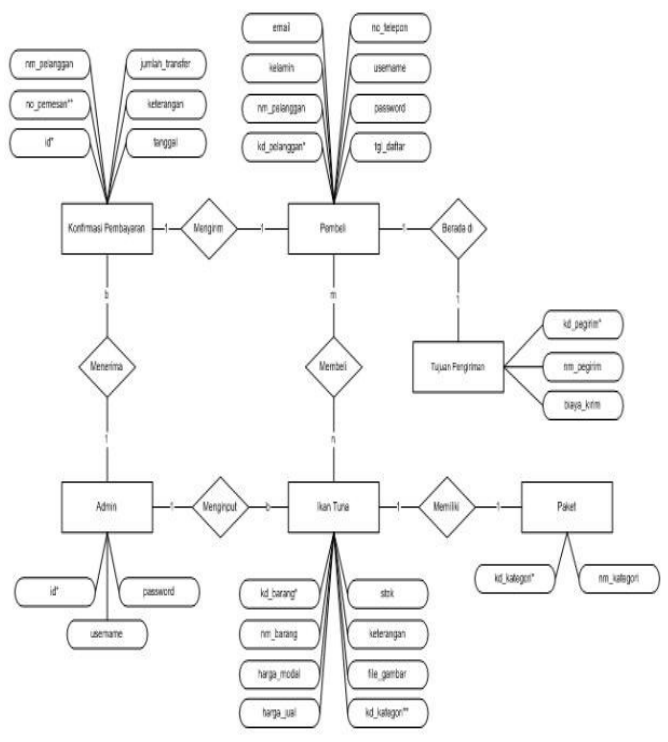

Gambar 4 Entity Relationship Diagram

\section{Relasi Tabel}




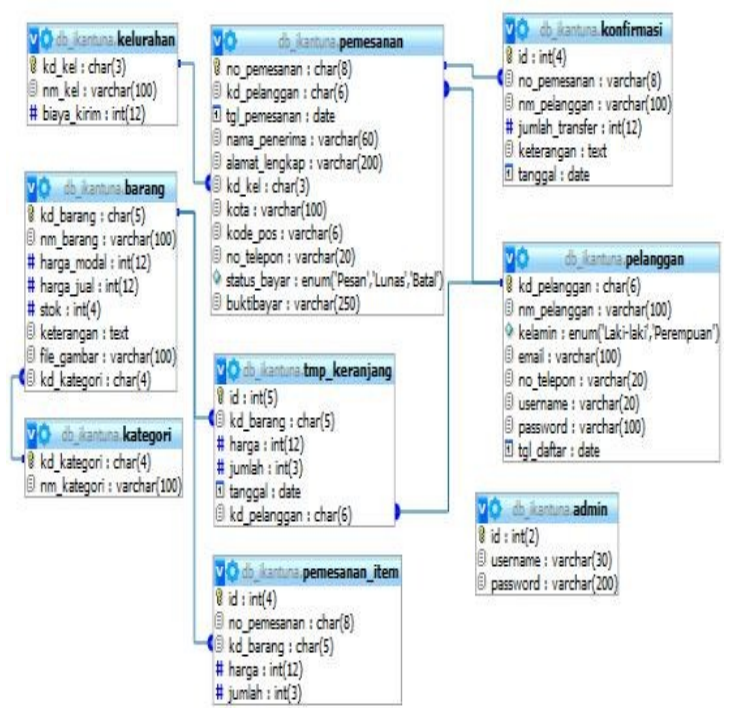

Gambar 5 Relasi Tabel

\section{IMPLEMENTASI DAN PEMBAHASAN}

Pembahasaan Pada bab ini akan dijelaskan mengenai implementasi Aplikasi yang dirancang.

\section{Halaman Utama User}

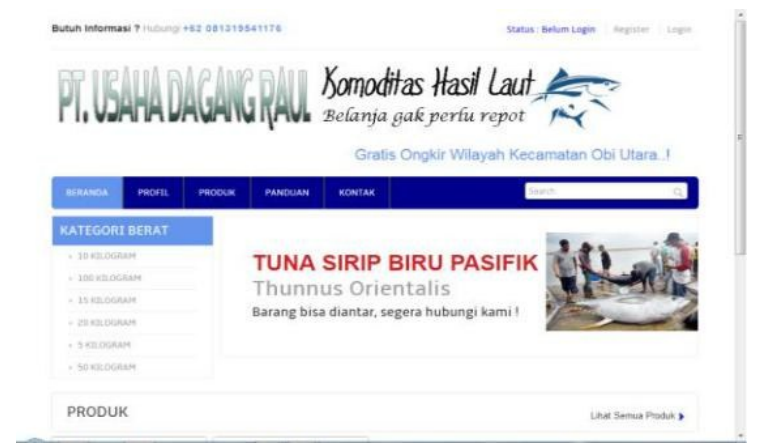

Gambar 6. Halaman Utama User

Ada gambar diatas dapat dijelaskan bahwa Halaman Utama User Merupakan Halaman awal yang ditampilkan ketikan pengunjung mengakses alamat Websiter. Pada halaman ini terdapat beberapa menu yaitu pada pojok kanan diatas terdapat menu registrasi dan login. Sedangkan pada bagian bawah Header terdapat menu beranda, Profil, Produk, Panduan dan Kontak..

\section{Halaman Produk}

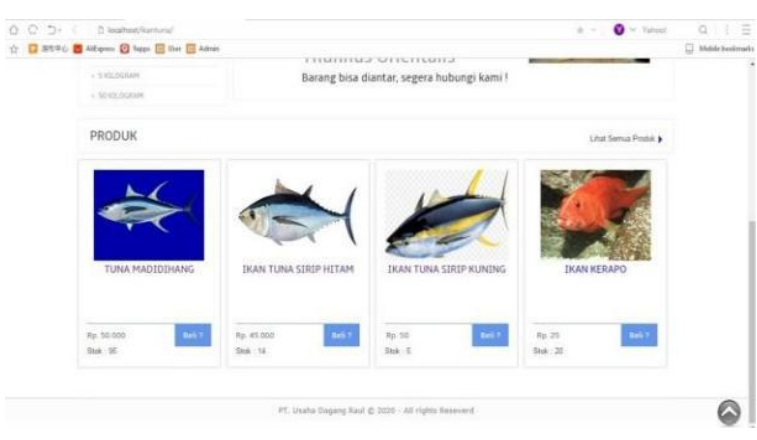

Gambar 7. Halaman Produk

Pada Gambar Halaman produk diatas dapat dijelaskan bahwa halaman yang menampilkan daftar data produk Ikan yang dijual. Dimana pada halaman produk terdapat empat produk Ikan Beserta Harganya yaitu Tuna Madidihang, Ikan Tuna Sirip Biru, Ikan Tuna Sirip Kuning Dan Ikan Kerapo. Apabila pelanggan melakukan pembelian maka pelanggan mengklik Menu Beli setelah itu dapat diproses.

\section{Halaman Keranjang Belanja}

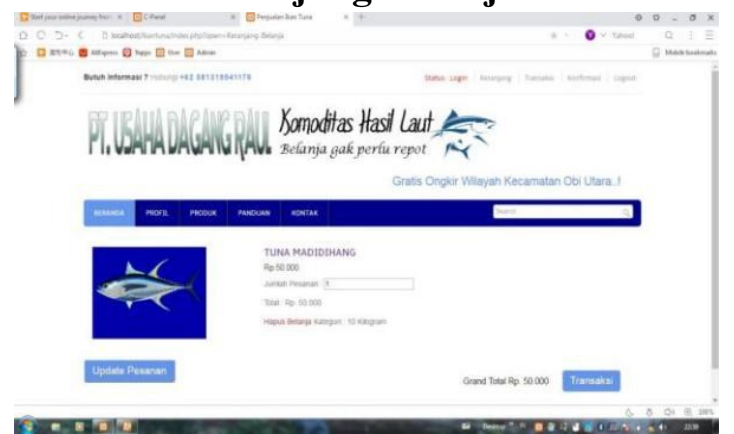

Gambar 8. Halaman Keranjang Belanja

Pada Gambar Halaman Keranjang Belanja diatas dapat dijelaskan pelanggan terlebih dulu melakukan registrasi dan login. Apabila pelanggan sudah melakukang registrasi maka pada menu situs login disebla kanan diatas secara otomatis dapat berubah menjadi situs login, apabila pelanggan belum melakukan registrasi dinyatakan situs belum login.

\section{Halaman Transaksi}




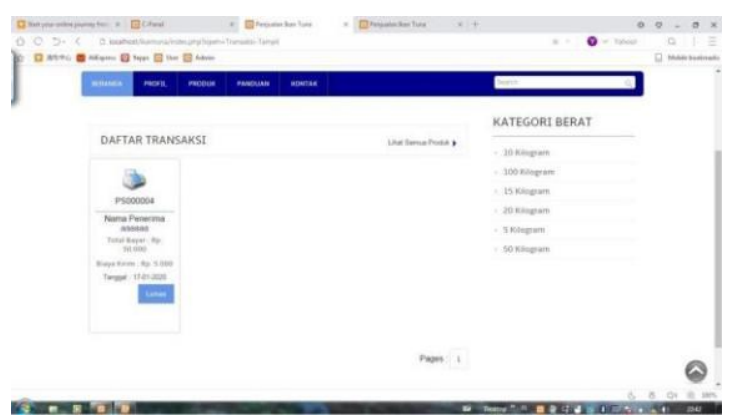

Gambar 9. Halaman Transaksi

Pada Gambar Halaman Transaksi diatas dapat dijelaskan bahwa didalam daftar transaksi terdapat kode pemesanan, nama penerim, total bayar, biaya kirim serta tanggal pengiriman. Apabila pelanggan sudah melakukan pembayaran maka pada menu transaksi dinyatakan lunas jika belum maka dinyatakan belum lunas. Disini penjual bisa saja membatalkan pengiriman apabila pelanggan tidak melakukan transaksi pembayaran

\section{Halaman Konfirmasi}

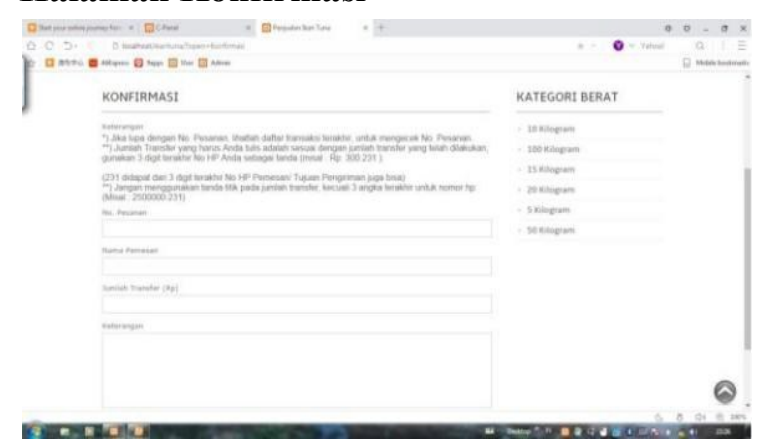

Gambar 10. Halaman Konfirmasi

Pada Gambar diatas dapat dijelaskan bahwa Halaman konfirmasi merupakan halaman untuk pelanggan memberikan pesan setelah melakukan transaksi pembayaran. dalam melakukan konfirmasi pembayaran terdapat beberapa tabel yaitu Keterangan pesanan, nomor pesanan, nama pesanan, jumlah tranfer dan keterang barang pesanan

\section{Tampilan Login Admin}

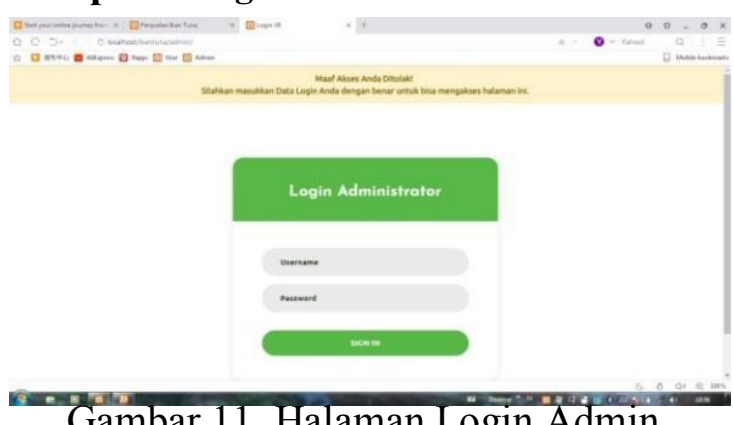

Gambar 11. Halaman Login Admin

Pada Gambar diatas dapat dijelaskan bahwa pada halaman ini terdapat sebuah from dan beberapa field input, yaitu username dan pasword, kemudian juga terdapat sebuah tombol login. Apabiala user ingin masuk kedalam halaman utama admin user diharuskan memasukan username dan pasword yang benar setelah itu klik menu Sign In agarbisa masuk kedalam halaman admin. Apbila username dan pasword yang dimasukan salah otomatis user tidak dapat masuk kedalam halaman admin.

\section{Tampilan Utama Admin}

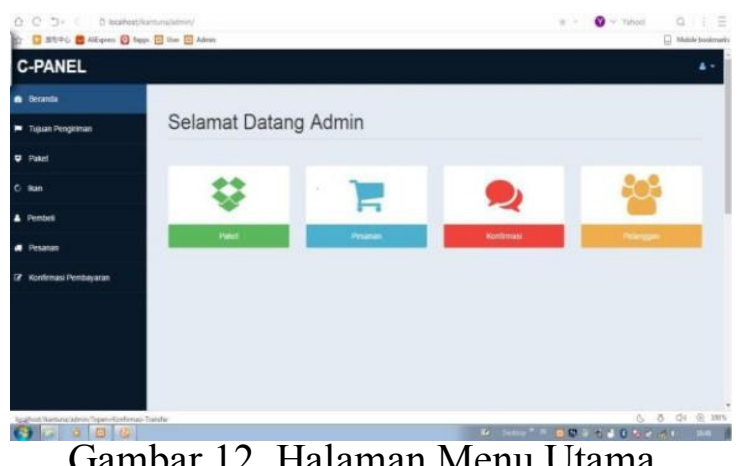

Gambar 12. Halaman Menu Utama

Pada Gambar diatas dapat dijelaskkan bahwa tampilan awal admin dimana tampilan paling awal ketika admin berhasil login kedalam sistem penjualan. Dimana pada halaman ini terdapat beberapa menu akses yaitu Beranda, Tujuan Pengiriman, Paket, Ikan, Pembeli, Dan Konfirmasi Pembayaran. Pada menu Beranda terdapa empat kategori yaitu 
Paket, Pesanan, Konfirmasi, dan Pelanggan.

\section{Halaman User Admin}

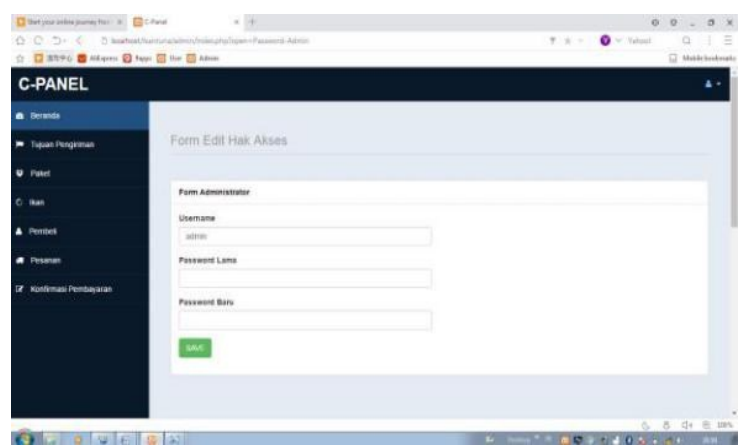

Gambar 13. Halaman User Admin

Pada Gambar diatas dapat dijelaskan bahwa Halaman user admin merupakan halaman yang menampilkan data user login untuk bisa mengakses halaman admin. Untuk masuk ke halaman ini halyang pertama dilakukan pengguna mengeklik pada menu User Profil yang ada pada pojok kanan diatas.jika sudah maka secara otomatis dapt masuk ke halaman From Edit Akses dimana didalamya terdapat username, Pasword Baru, dan Pasword Lama.

\section{Tampilan Data Tujuan Pengiriman}

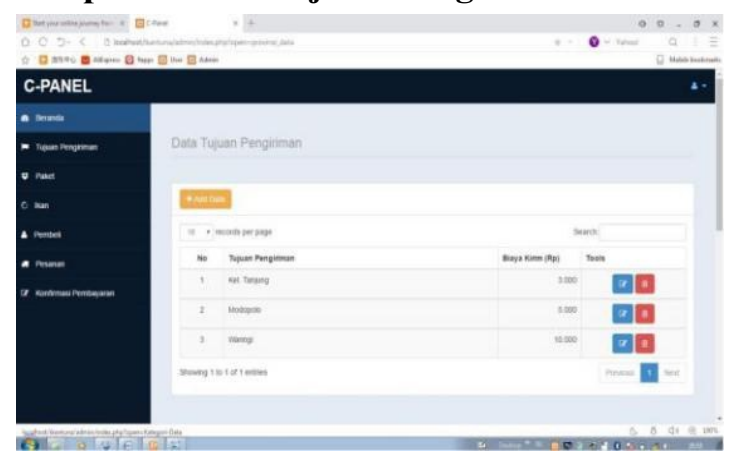

Gambar 14. Halaman Tujuan Pengiriman

Pada Gambar dimana pada halaman ini dapat dijelaskan Pada menu tujuan pengiriman terdpat beberapa tabel Diantaranya Yaitu Nomor, Tujuan Pengiriman, Biaya Kirim Dan Tools. Pada halaman ini administrator dapat melakukan beberapa pengelolaan data, antara lain adalah Tambah, Edit dan Hapus.

\section{Tampilan Data Ikan}

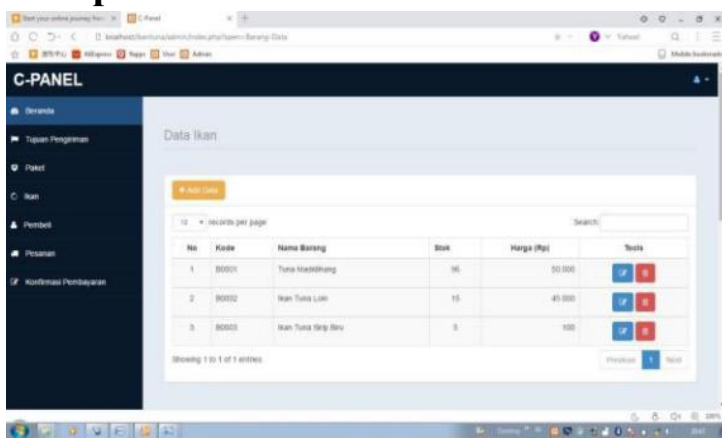

Gambar 15. Halaman Data Ikan

Pada Gambar diatas dapat dijelaskan bahwa Halaman data Ikan merupakan halaman untuk daftar data ikan yang ada pada PT UD RAUL untuk dipromosikan dan dijual kepada pelanggan dimana pada halam ini terdapat beberapa tabel yaitu Nomor, Kode Barang, Jumlah Stok, Haraga Dan Tool. Pada halaman ini administrator dapat melakukan beberapa pengelolaan data, antara lain adalah Tambah, Edit dan Hapus.

\section{Tampilan Data Pembeli}

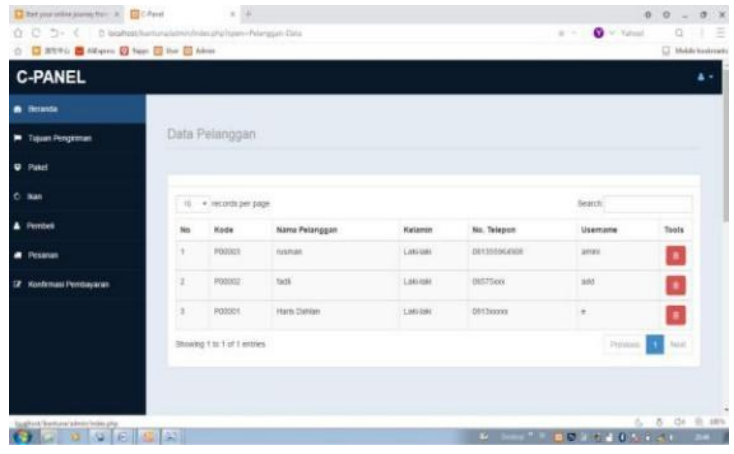

Gambar 16. Halaman Data Pembeli

Pada Gambar diatas dapat dijelaskan bahwa Halaman data pembeli merupakan halaman yang menampilkan data pembeli yang telah melakukan pendaftaran untuk 
melakukan pembelian dimana pada halaman ini terdapat beberapa tabel yaitu nomor, Kode, Nama Pelanggan, Kelamin, Nomor Telpon, Username Dan Tools. Pada halaman ini administrator dapat melakukan beberapa pengelolaan data, antara lain adalah Tambah, Edit dan Hapus.

\section{Tampilan Data Pesanan}

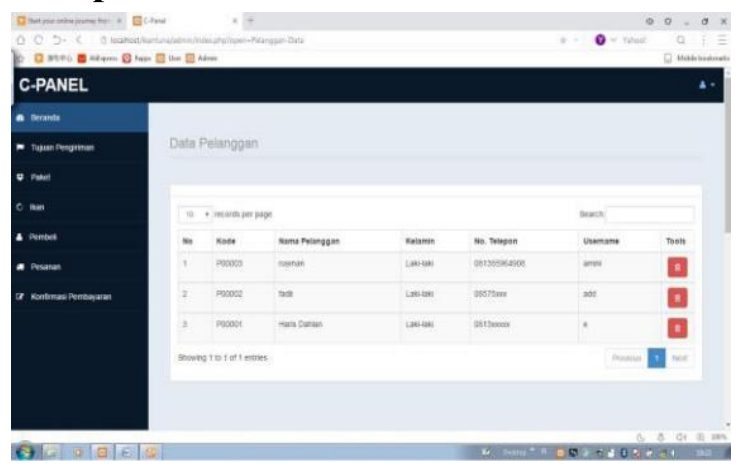

Gambar 17. Halaman Data Pemesanan Barang

Pada Gambar dapat dijelaskan bahwa Halaman data pesanan merupakan halaman yang menampilkan daftar data transaksi pemesanan barang yang dilakukan oleh pembeli. Dimana pada halaman ini terdapat beberapa tabel yaitu Nomor, Kode, Nama Pelanggan, Kelamin, Nomor Telpon, Username dan Tools. Pada halaman ini administrator dapat melakukan beberapa pengelolaan data, antara lain adalah Tambah, edit dan hapus.

\section{Tampilan Data Konfirmasi Transfer}

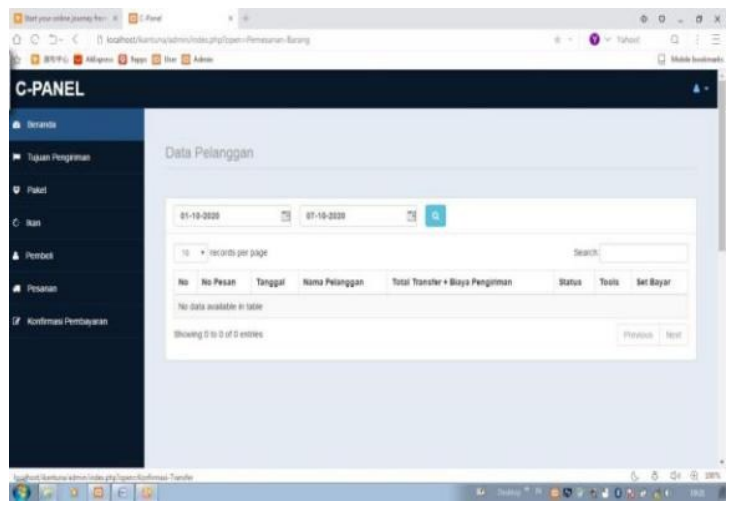

Gambar 18. Halaman Data Konfirmasi Transfer

Pada Gambar diatas dapat dijelaskan bahwa Halaman data konfirmasi transfer merupakan halaman yang menampilkan data konfirmasi dari pelanggan setelah melakukan transaksi pembelian. Pada halaman ini terdappat beberapa tabel yaitu nomor, Tanggal Nomor Pesan, Nama Pelanggan,Total Tranfer Serta Biaya Pengiriman, Status, Tools Dan Set Bayar.

\section{KESIMPULAN}

Berdasarkan penjelasan dan uraian, maka dapat di ambil kesimpulan sebagai berikut :

1. Website yang telah dibuat dapat memperluas ruang lingkup promosi di karenakan berbasis web yang dapat di akses di berbagai tempat dan daerah.

2. Konsumen diberikan kemudahan dalam pemilihan produk karena pada web ini telah dilengkapi fasilitas info produk secara rinci.

3. Memudahkan admin dalam mengolah produk, pengiriman karena semua fitur dan menu tersusun secara sistematis.

4. Website yang dibangunn ini mempermudah konsumen dalam melakukun pemesanan produk.

\section{Saran}

Perancangan website ini masih memiliki berbagai keterbataasan, sehingga perlu dilakukan pengembangan sistem selanjutnya di masa mendatang. Saran penulis untuk pengembangan siste $\mathrm{m}$ antara lain :

1. Perlu adanya peningkatan keamanan dalam transaksi, untuk pengembangan sistem selanjutnya dapat menjamin data dan transaksi konsumen. 
2. Tampilan web yang lebih atraktif, bias dengan menggunakn Falsh.website Dapa disempurnakan dengan menyertakan fasilitas notifiksi bagi oprator untuk mengetahui jika ada pesanan prodok atau pertanyaan-pertanyaan.

\section{DAFTAR PUSTAKA}

Bella, Semlinda, 2017, Penerapan Busines sTo Customer (B2c) Pada Sistem Penjualan Ikan Bakar Di L2b Berbasis Android.

Nugroho, A., 2006, Commerce Memahami Perdagangan Modern di dunia Maya, Informatika, Bandung.

Sunarto, Andi, 2009, Seluk Beluk eComme rce, Graha Ilmu, Yogyakarta.

Sommerville, L., 2011, Software Engineri ng (Rekayasa Perangkat Lunak),

Erlangga, A, 2014, Perancangan Website Sebagsi Media Promosi Dan Penjualan Pada Home Industry Abon.

Qurnia, D, (2014), Media Promosi Dan Penjualan Pada New Sisterz Butik S m arang Dengan Menggunakan Metode WebEngineering.

Ni Luh Made Rhapsari Putri, D,(2015) Perencanaan Pemasaran Tah Tuna pa da Usaha Mikro Nabilla Makmur di Pacitan, Jawa Timur.

Whitten, J L. Bentley, L D. Dittman, K C.2013.

Use Case Diagram.https://www.googl e.com/search/Use + Case+Diagram/( pada Tanggal 01 Mei 2019, Pukul 12.30) 